\title{
Pneumocystis jirovecii in HIV patients and suspected pneumonia: a problematic diagnosis in Caracas, Venezuela.
}

\author{
María Mercedes Panizo ${ }^{1}$, Giuseppe Ferrara ${ }^{1}$, Nataly García ${ }^{1}$, Vera Reviakina ${ }^{1}$, \\ Trina Navas ${ }^{2}$, Xiomara Moreno ${ }^{3}$, Ana María Capote ${ }^{1}$, Maribel Dolande ${ }^{1}$, \\ Víctor Alarcón ${ }^{1}$ and Enrique Calderón ${ }^{4}$ \\ ${ }^{1}$ Departamento de Micología, Instituto Nacional de Higiene Rafael Rangel. Caracas, \\ Venezuela. \\ ${ }^{2}$ Hospital General del Oeste Dr. José Gregorio Hernández. Caracas, Venezuela. \\ ${ }^{3}$ Instituto Médico La Floresta. Caracas, Venezuela. \\ ${ }^{4}$ Centro de Investigación Biomédica en Red (CIBER) de Epidemiología y Salud Pública/ \\ Instituto de Biomedicina de Sevilla, Hospital Universitario Virgen del Rocío/CSIC/ \\ Universidad de Sevilla, Sevilla, España.
}

Key words: AIDS; direct immunofluoreseence; HIV infection; nested PCR; Pneumocystis jirovecii.

\begin{abstract}
Pneumocystis jirovecii pneumonia (PCP) is one of the most frequent opportunistic infections in immunocompromised patients. The objective of this study was to know the P. jirovecii epidemiology in Venezuelan patients with Human Immunodeficiency Virus (HIV) infection and suspected pneumonia, through passive surveillance at a national reference laboratory during six years. Laboratory records of patients with HIV infection, who were hospitalized with acute lower respiratory tract infection (ALRTI), and presumptive clinical diagnosis of PCP, were reviewed between January 2007 and December 2012, at the Mycology Department of the Instituto Nacional de Higiene Rafael Rangel. Several respiratory specimens were received and the direct immunofluorescence assay (DIF) and nested polymerase chain reaction (nPCR) diagnostic techniques were used. One hundred and sixty-one respiratory samples were processed and $P$. jirovecii was detected in 76 samples by DIF and in 20 by nPCR. PCP's frequency in Venezuelan patients with HIV is high and it has been sustained throughout time. Colonization by $P$. jirovecii has uncertain clinical significance, but this study provides evidence that the state of advanced immunosuppression increases the probability of colonization. DIF and nPCR are very useful techniques for PCP diagnosis, but are of limited access in many hospital centers, especially in developing countries. We recommend the use of DIF with spontaneous sputum specimens as the first diagnostic line for PCP in patients with HIV infection. The results obtained by nPCR should be interpreted with caution, taking into account the patient's clinical symptoms.
\end{abstract}

Corresponding author: María Mercedes Panizo. Departamento de Micología, Instituto Nacional de Hiǵiene Rafael Rangel. Caracas, Venezuela. Phone: +584166060257. Email: mmpanizo@gmail.com 


\title{
Pneumocystis jirovecii en pacientes con infección por el VIH y sospecha de neumonia: un diagnóstico problemático en Caracas, Venezuela.
}

\author{
Invest Clin 2020; 61 (3): 196-211
}

Palabras clave: SIDA; inmunofluorescencia directa; infección por VIH; PCR anidada; Pneumocystis jirovecii.

Resumen. La neumonía por Pneumocystis jirovecii (PCP) es una de las infecciones oportunistas más frecuente en pacientes inmunocomprometidos. El objetivo de este trabajo fue conocer la epidemiología del $P$. jirovecii en pacientes venezolanos con infección por el Virus de Inmunodeficiencia Humana (VIH) y sospecha de neumonía, mediante vigilancia pasiva en un laboratorio de referencia nacional durante un período de 6 años. Se revisaron los registros de laboratorio de los pacientes con infección por el VIH hospitalizados con Infección Aguda del Tracto Respiratorio Inferior (IATRI) y diaǵnóstico clínico presuntivo de PCP, entre enero de 2007 a diciembre de 2012 en el Departamento de Micología del Instituto Nacional de Higiene Rafael Rangel. Se recibieron diversas muestras del tracto respiratorio y los métodos diaǵnósticos empleados fueron inmunofluorescencia directa (IFD) y reacción en cadena de la polimerasa anidada (nPCR). Se procesaron 161 muestras respiratorias y se detectó $P$. jirovecii en 76 muestras por IFD y en 20 por nPCR. La frecuencia de PCP en pacientes venezolanos con HIV es elevada y se ha mantenido en el tiempo. La colonización por $P$. jirovecii tiene un significado clínico incierto, pero este estudio aporta evidencia de que un estado avanzado de inmunosupresión incrementa la probabilidad de colonización. La IFD y la nPCR son técnicas muy útiles para el diagnnóstico de la PCP, pero son de acceso limitado en muchos centros hospitalarios, sobre todo en países en vías de desarrollo. Recomendamos la utilización de la IFD con muestras de esputo espontáneo como primera línea de diagnóstico para la PCP en pacientes con VIH. Los resultados obtenidos por nPCR deben ser interpretados tomando en cuenta la sintomatología clínica del paciente.

Received: 20-01-2020 Accepted: 17-06-2020

\section{INTRODUCTION}

Pneumocystis jirovecii is an atypical fungus that causes pneumonia in immunocompromised patients. It is considered a disease that marks the presence of Acquired Immunodeficiency Syndrome (AIDS), and is one of the most frequent opportunistic infections. Due to the lack of availability of standardized methods for its conventional culture, the di- agnosis of the disease has been performed by demonstrating its morphotypes, asci and ascospores, in various respiratory specimens using special stains (1-3).

The most frequently used specimens are spontaneous sputum (SS), induced sputum (IS), bronchoalveolar lavage (BAL) and lung biopsy. P. jirovecii can be viewed using Giemsa stain, Gomori methenamine silver stain, Toluidine blue O stain and immuno-

Vol. 61(3): 196 - 211, 2020 
fluorescence assay. Direct immunofluorescence assay (DIF) is currently considered the preferred technique for the diagnosis of P. jirovecii pneumonia (PCP) due to its high sensitivity and specificity (1,3-6). However, the polymerase chain reaction (PCR) has proven to be more sensitive in detecting $P$. jirovecii than the aforementioned stains. The differentiation between colonization and infection using this technique requires that its results be interpreted with caution, taking always into account the patient's symptomatology, since it ean detect this fungus in asymptomatic patients $(1,3,5,7,8)$.

In Venezuela, the $P$. jirovecii epidemiology is not well known in human immunodeficiency virus (HIV) infected patients and to date, carried out studies are scarce $(4,6,7,9,10)$. PCP diagnosis is usually elinical and has a significant impact on morbidity and mortality, especially when there are no complementary laboratory tests that confirm the etiological diagnosis, due to the absence of microbiological diagnosis, and especially, mycological diagnosis in the hospital centers $(6,11,12)$.

The objective of this study was to know the $P$. jirovecii epidemiology in Venezuelan patients with HIV infection and suspected pneumonia, through a laboratory-based surveillance of a national reference center during a period of six years.

\section{MATERIALS AND METHODS}

A cross-sectional, descriptive, and retrospective study was designed within the period from January 2007 to December 2012. We reviewed laboratory records of patients with HIV infection, hospitalized with acute respiratory infection of the lower respiratory tract (ALRTI) and clinical suspicion of PCP.

The first report of the incidence of PCP through passive surveillance in Venezuela was published by the Mycology Department of the Instituto Nacional de Higiene Rafael Rangel (INHRR), in 2008. The laboratory records from patients with a presumptive diagnosis of lower respiratory tract infection were reviewed during a six-year period (2001-2006) (6). Therefore, this is the second incidence report of PCP through passive surveillance, but only taking into account HIV patients. Since 2012, reagents became scarce and the diagnosis could not be carried out properly; finally, since 2013 the necessary reagents were not available any more, which caused the suspension of passive surveillance of the disease.

Respiratory samples from patients with HIV infection were referred to the Mycology Department of the INHRR, from several public and private hospital centers, located in the city of Caracas, accompanied by a request for the detection of $P$. jirovecii (Hospital Universitario de Caracas, Hospital del Seguro Social Dr. Domingo Luciani, Hospital General del Oeste Dr. Jose Gregorio Hernández, Hospital de Niños Dr. J.M. de los Ríos, Hospital Militar Dr. Carlos Arvelo, Hospital del Seguro Social Dr. Miǵuel Pérez Carreño, Hospital Dr. Jose Maria Vargas, Instituto Médico La Floresta, Clínica Santa Sofia and Clínica Vista Alegre). The development of this work was carried out respecting the guidelines regarding the processing of biological samples of human origin, according to the principles of the Declaration of Helsinki.

Demographic data, lymphocyte population count, HIV viral load, serological tests for antibodies detection against other virus and fungi, signs and symptoms, radiological findings, and treatments available in the laboratory database, were collected.

A patient with any positive sample for the detection of $P$. jirovecii by DIF or nested PCR (nPCR) as the first diagnosis was defined as a case. For the purpose of this study, a single case reported positive per patient was taken into account.

Several respiratory specimens were processed, such as spontaneous sputum (SS), induced sputum (IS), bronchoalveolar lavage (BAL) and lung biopsy. DIF was performed using the Merifluor ${ }^{\circledR}$ Pneumocystis kit (Me- 
ridian Bioscience, Inc.). Manufacturer's instructions for the processing of the IS, BAL and biopsy samples were followed, with some modifications in the processing of SS samples, standardized in the INHRR Mycology Department $(4,6)$. The sediments obtained from the samples were divided into two aliquots: one for DIF assay and one for nPCR. DIF was performed following the manufacturer's instructions. As a positive control, a BAL specimen from an AIDS patient with PCP clinical diagnosis, and staining of Gomori methenamine silver, and DIF positive for P. jirovecii was used.

The nPCR was earried out following the protocol described by Wakefield et al., with modifications $(7,13,14)$. Briefly: DNA was extracted from the aforementioned samples using the protocol for tissues of the QLAamp DNA Mini Kit (QLAGEN) (DNA yields between 15-20 $\mu \mathrm{g}$ ). In the first round of amplification, $10 \mathrm{mM}$ Tris-HCl ( $\mathrm{pH} 8.8$ ) buffer so-

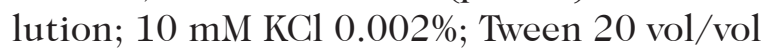
(First Strand Buffer, Invitrogen); $50 \mathrm{mM}$ of $\mathrm{MgCl}_{2}$ (Invitrogen); $100 \mathrm{mM}$ of oligonucleotides (Invitrogen); $0.1 \mathrm{mM}$ of dithiothrietol (Invitrogen); $40 \mathrm{U} / \mu \mathrm{L}$ of recombinant ribonuclease inhibitor (Invitrogen); $10 \mathrm{mM}$ each of pAZ102-E and pAZ102-H external primers (Molecular Bioscience Inc); $5 \mathrm{U} / \mu \mathrm{L}$ of recombinant Taq DNA polymerase (Invitrogen); extracted DNA, and nuclease free water (Invitrogen) were used, for a final volume of 50 $\mu \mathrm{L}$. The second round of amplification was performed with the DNA resulting from the first round of amplification, $10 \mathrm{mM}$ each of pAZ102-X and pAZ102-Y internal primers (Molecular Bioscience Inc) and the same reagents mentioned above, for a final volume of $50 \mu \mathrm{L}$. Both $\mathrm{nPCR}$ rounds were performed on an iCycler ${ }^{\circledR}$ model thermal cycler (BioRad Laboratories) under the same conditions: $94^{\circ} \mathrm{C}$ for $1.5 \mathrm{~min}$; 40 cycles with $94^{\circ} \mathrm{C}$ for $1.5 \mathrm{~min}, 55^{\circ} \mathrm{C}$ for $1.5 \mathrm{~min}$ and $72^{\circ} \mathrm{C}$ for 2 min, and a final extension of $72^{\circ} \mathrm{C}$ for $5 \mathrm{~min}$.

The products generated in the second nPCR round were subjected to an electrophoresis at 120 volts on a $2 \%$ agarose gel stained with ethidium bromide. Products were visualized in an image documentation system (Gel Doc XR ${ }^{\circledR}$, Laboratorios Bio$\mathrm{Rad})$. The presence of a $260 \mathrm{bp}$ band in the second round was considered as a positive sample. As controls for the nPCR the following were used: samples positive control (the same used in the DIF tests), samples negative control (BAL sample of an AIDS patient with ALRTI clinical diagnosis and staining of Grocott methenamine silver, and DIF negative for $P$. jirovecii), and control reagents. They all were processed under the same conditions in which the samples under study were treated.

For the purposes of this study, patients with a positive result by DIF were referred to as $\mathrm{Pj}+$; patients with a negative result by DIF but with a positive result by nPCR were referred to as $\mathrm{Pjc}+$; and patients with negative results by DIF were referred to as $\mathrm{Pj}$-. The obtained data was described by means of percentages, average and standard deviation. Qualitative variables were compared using Chi square test $\left(\mathrm{X}^{2}\right)$ or Fisher's exact test. Continuous variables were compared using Mann Whitney test. Statistical significance was accepted for a value of $p<0.05$ and a confidence level of $95 \%$. Analyses were performed using the Statgraphics Centurion XVII program.

\section{RESULTS}

During a six-year period, 161 respiratory specimens were received from hospitalized patients with HIV infection, ALRTI and PCP clinical suspicion. In 76 of 161 samples $P$. jirovecii $(\mathrm{Pj}+)$ was detected by DIF (47.2\%); in 36 of 76 samples nPCR was performed in parallel obtaining positive results; in 8 of 76 nPGR was negative, and in the remaining 32 of 76 specimens this technique could not be performed, because the necessary reagents were not available. In 85 of 161 samples DIF result was negative; in 65 of $85 \mathrm{nPCR}$ was negative $(\mathrm{Pj}-)$, whereas in 20 of $85(\mathrm{Pjc}+)$ nPCR was positive (23.5\%).

Vol. 61(3): 196 - 211, 2020 
In all, 96 patients had a positive result for $P$. jirovecii detection (39\%).

The demographic characteristics (gender and age), immunological condition and processed respiratory specimens of the patients are shown in Table I. The data about immunological condition were not available for all the patients. The average value of CD4 $\mathrm{T}$ cell count was similar in $\mathrm{Pj}+, \mathrm{Pjc}+$ and $\mathrm{Pj}$ - patients. Eighty six point seven percent (39 of $45 \mathrm{Pj}+$ ), 85.7\% (12 of $14 \mathrm{Pjc}+$ ), and 83.8\% (31 of $37 \mathrm{Pj}$ ) had counts lower than 200 cells $/ \mathrm{mm}^{3}$, where 20 of $39 \mathrm{Pj}+(44.4 \%), 7$ of $14 \mathrm{Pjc}+(50 \%)$ and 18 of $31 \mathrm{Pj}-(48.6 \%)$ had counts $<50$ cells/ $\mathrm{mm}^{3}$. When comparing the results obtained from these variables, among $\mathrm{Pj}+, \mathrm{Pjc}+$ and $\mathrm{Pj}$ - patients, statistically significant differences were not obtained $(\mathrm{p}>0.05)$.

Co-infections and treatments received from HIV-infected patients included in this study are shown in Table II. This information was not available in all the patients. In 76 patients $\mathrm{Pj}+$, ALRTI was the most frequent followed by pneumonia (of unknown etiology) and tuberculosis (TB), while in Pje+ and $\mathrm{Pj}$ - patients, the results were similar, where the ALRTI followed by TB were the most frequent infections.

In addition, the presence of antibodies against hepatitis $\mathrm{B}(\mathrm{n}=4)$, cytomegalovirus $(n=3)$ and hepatitis B plus cytomegalovirus $(n=1)$ were serologically confirmed in eight $\mathrm{Pj}+$ patients. In the $\mathrm{Pjc}+$ patients, the presence of antibodies was confirmed in one patient who presented cytomegalovirus plus Epstein Barr virus and herpes simplex virus. In the $\mathrm{Pj}$ - patients, the presence of antibodies was confirmed in six patients: cytomegalovirus $(n=3)$, hepatitis $B(n=2)$ and hepatitis $C$ $(n=1)$. As for the serological tests to detect the presence of circulating antibodies against endemic fungi such as Histoplasma capsulatum, Paracoccidioides spp. and Coccidioides spp., in the $\mathrm{Pj}+$ patients the test was positive for $H$. capsulatum for a single patient (title 1:2, nondiagnostic value for the disease), negative in 35 and was not requested in 40. In Pje+ patients, the test was negative in eight patients and was not requested in 12 ; in $\mathrm{Pj}$ - patients the test was negative in 34 , it was not requested in 30 patients and was positive for H. capsulatum in one patient (title 1:2, non-diagnostic value for the disease). In a Pj- patient the capsular antigen detection test for Cryptococcus Species Complex was additionally performed by latex agglutination in cerebrospinal fluid, which was positive with a diagnostic title for the infection (>1:1024).

The most frequently antiretroviral drugs (ARVs) used for the treatment of HIV-infected patients included in this study were nucleoside reverse transcriptase inhibitors, nonnucleoside reverse transcriptase inhibitors, protease inhibitor and combinations thereof. Of these, 12 of $76 \mathrm{Pj}+, 7$ of $20 \mathrm{Pjc}+$ and 9 of $65 \mathrm{Pj}$ - patients were on ARV treatment at the time of $P$. jirovecii detection, but no information on duration and adherence was obtained in any of the groups (Table II). The most frequently used antibiotics were third and fourth generation cephalosporins, betalactams associated with beta-lactamase inhibitors, ǵlycopeptides, aminoglycosides, macrolides and quinolones; among the antifungals, the most common were amphotericin $\mathrm{B}$, fluconazole and itraconazole, and among the antivirals were valganciclovir and acyclovir. Only 15 of $76 \mathrm{Pj}+, 2$ of $20 \mathrm{Pje}+$ and 10 of 65 $\mathrm{Pj}$ - patients had prophylactic treatment with trimethoprim/sulfamethoxazole (TMP/SXT) at the time of $P$. jirovecii detection, and in no case information on treatment compliance and the duration of it was obtained.

The signs, symptoms and radiological findings of HIV-infected patients, according to the results of the P. jirovecii detection, are shown in Table III. Dyspnea, cough, expectoration, fever and chest pain were the most frequent signs and symptoms in the three groups of patients; other less frequent but important symptoms in both groups were asthenia and lymphadenopathy, among others. As for the radiological findings, diffuse bilateral infiltrate and bilateral interstitial infiltrate were the most frequent, but the latter predominated in the $\mathrm{Pj}$-group. 


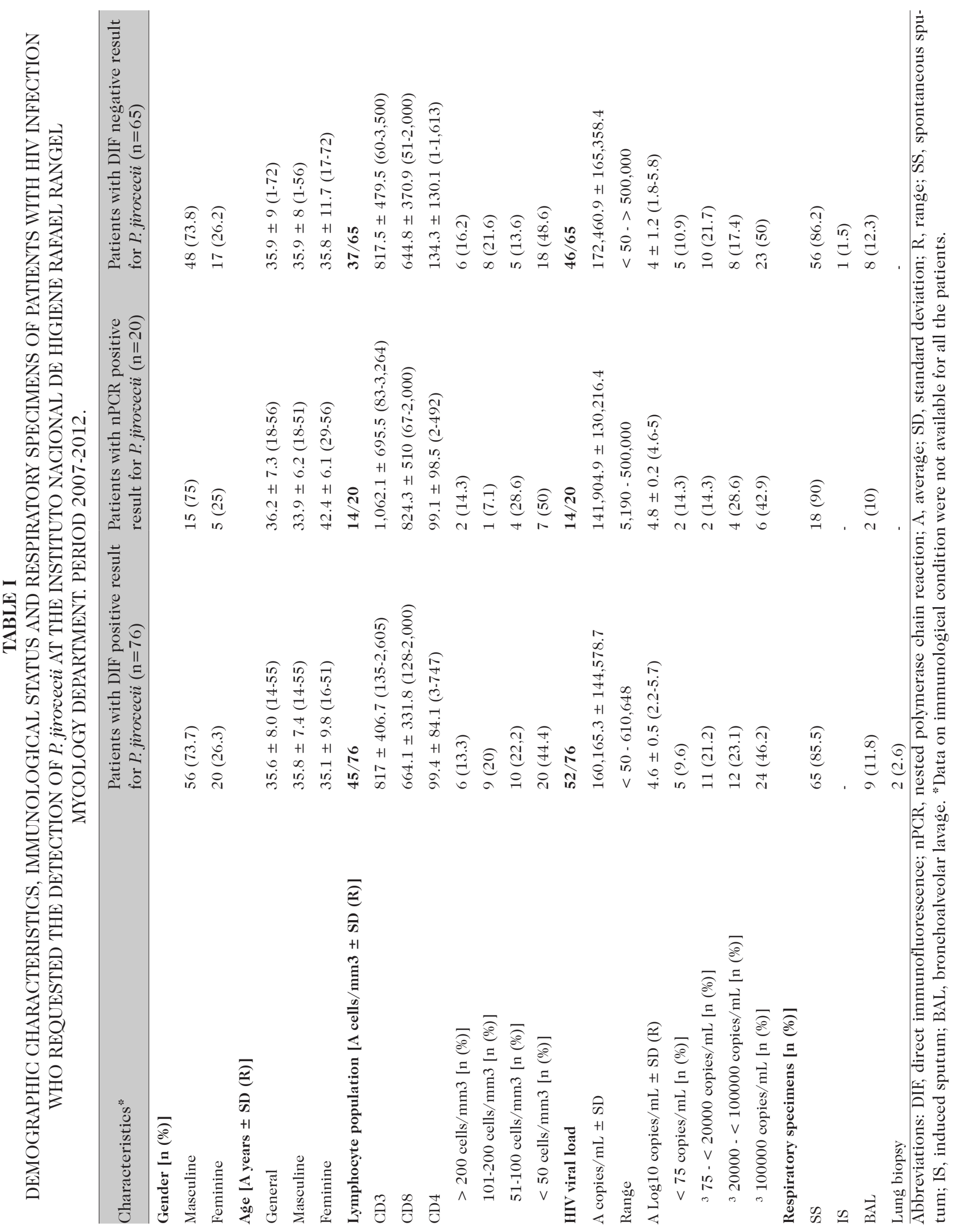




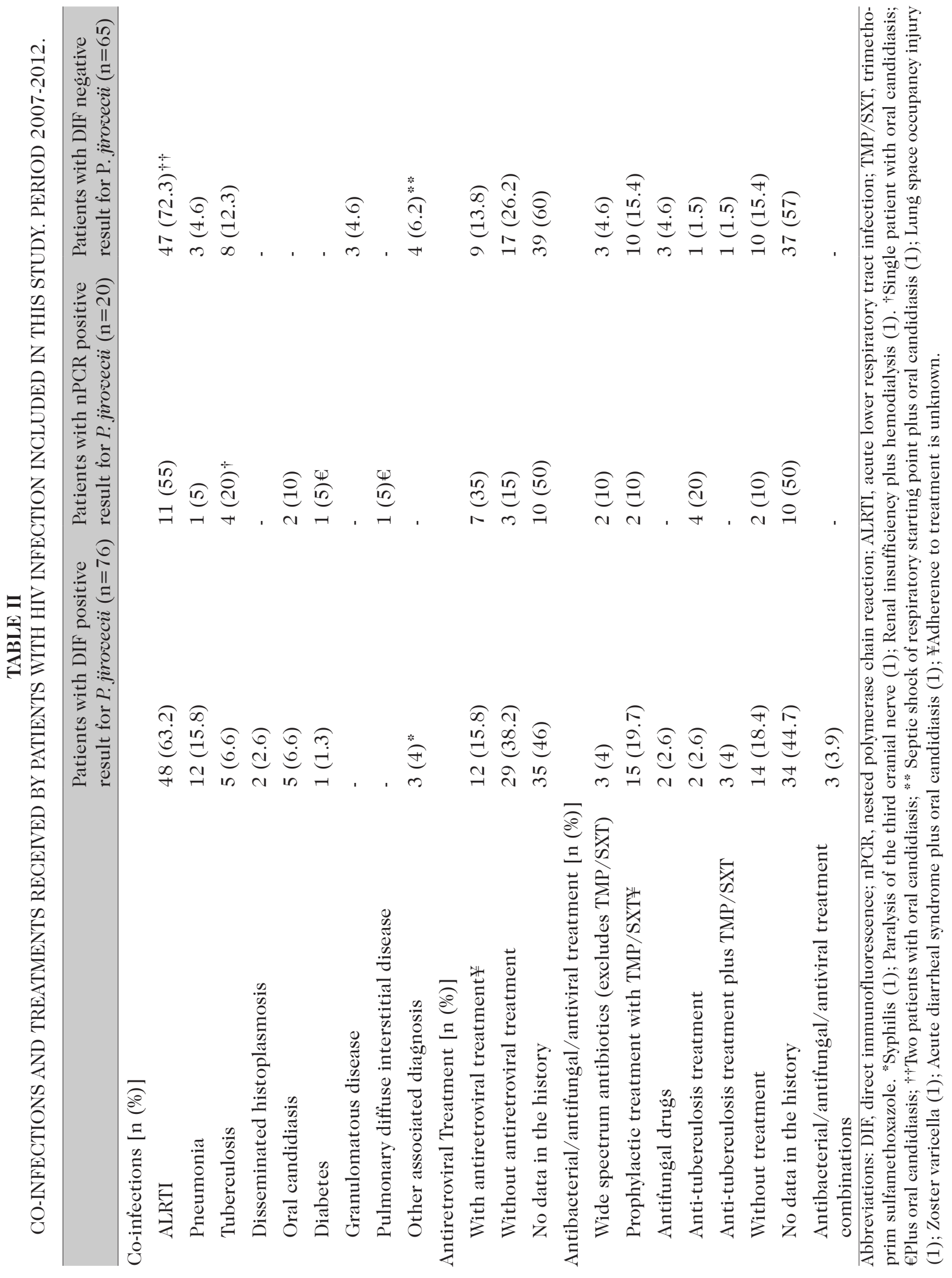




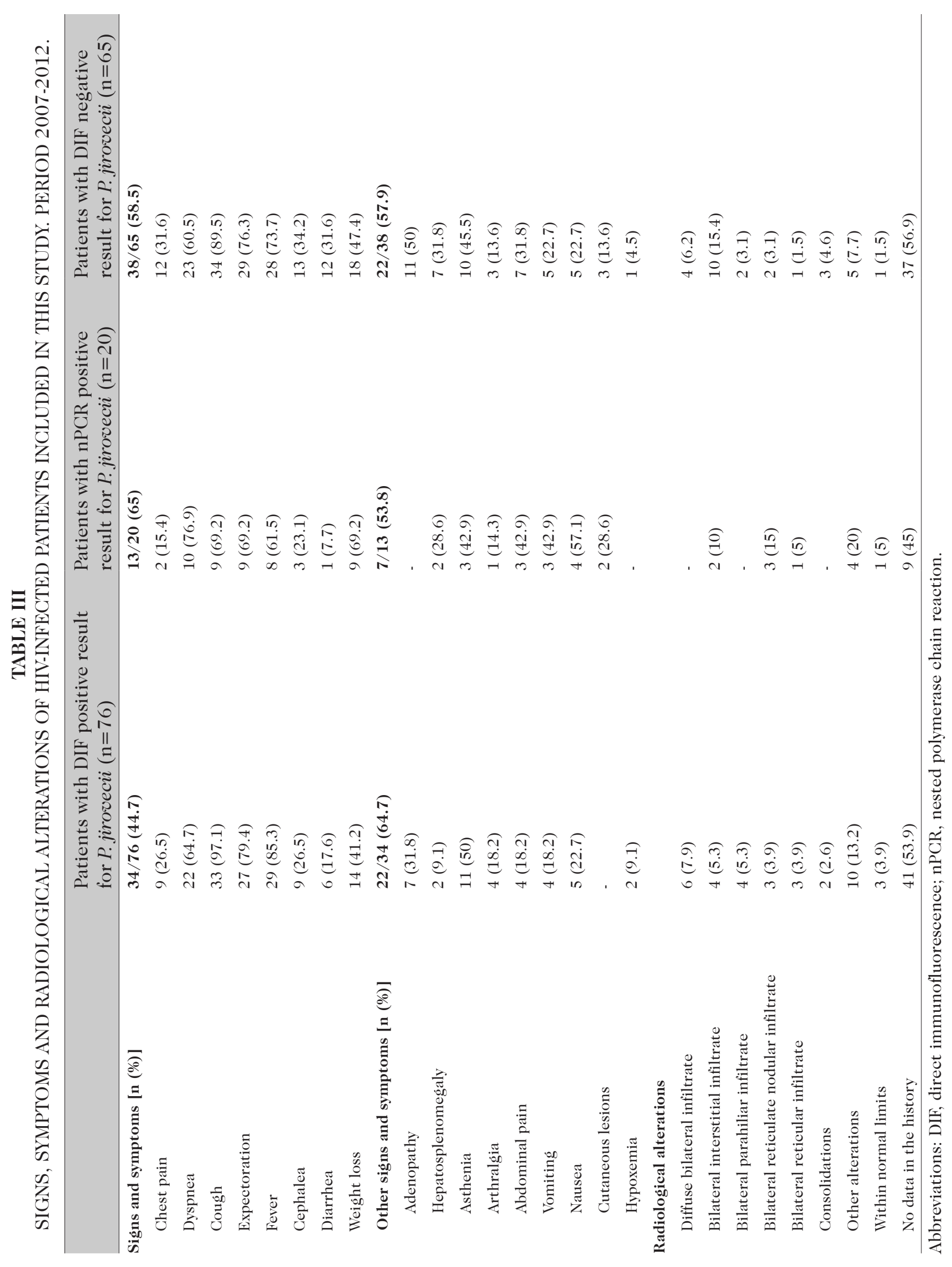




\section{DISCUSSION}

Studies on PCP in Venezuela are scarce and its epidemiology is not well known $(4,6,7,9,10)$. This is mainly due to the fact that this disease is not considered in the differential diagnosis of opportunistic infections in immunosuppressed patients with and without HIV infection, as well as the absence of diagnostic methods in hospital centers. In the case of this study, patient's specimens were referred to the INHRR from public and private hospitals, which do not have the necessary methods to diagnose this disease.

The comparison between the results of this study and those of other research, according to the frequency of the disease, gender, age, CD4 T cell count, HIV viral load, types of specimens used, diagnostic techniques used, signs and symptoms, prophylactic treatment with TMP/SXT, ARV treatment and interstitial infiltrate, considered the most common radiological alteration in patients with HIV infection and PCP, is shown in Table IV.

According to the results of this study, a $47.2 \%$ frequency of PCP diagnosed by DIF was obtained in patients with HIV infection, registering an increase of $10.6 \%$ compared to the previous study, which reported a 36.6\% using the same technique (6). The PCP frequency in patients with HIV infection and AIDS in Latin America is highly variable, with ranges between $5.9 \%$ and $55 \%$. This variation is due to differences in the studies design, heterogeneity of studied patients and the methods used to make the diagnosis. In comparison with the reports of the decline in the incidence of this disease in developed countries, subsequent to the introduction in Latin America of the highly active antiretroviral therapy (HAART), PCP frequency in patients with HIV infection and AIDS appears to remain stable, but with a tendency to increase in time $(11,12)$.

The PCP frequency reported in patients with AIDS according to European studies
(15-17), Asian studies $(1,2,18)$, and one African study (19), as well as in Latin America, depends on the variables mentioned above. The absence of data on the immunological status of the patient, evaluation of signs and symptoms, treatments and radiological image registration were common findings in the studies consulted, and prevented adequate comparisons. However, it was observed that the frequency of the disease is high, the male gender continues to be the most affected, with the exception of the work done by Ebner L, et al. (17) and the average age was very similar among all studies.

The CD4 T cell count is the biggest risk predictor for PCP development, and today it is better than any other biomarker or clinical characteristic. The results obtained in this study are quite similar to those found in other research $(1,2,15-19)$. There is no cutoff value for $\mathrm{CD} 4 \mathrm{~T}$ cell counts related to the development of this disease, however, the 200 cell $/ \mathrm{mm}^{3}$ count has been used for analytical purposes. For counts of 400 to 600 cells/ $\mathrm{mm}^{3}$ the risk is low but not absent. With 50 cells $/ \mathrm{mm}^{3}$ counts, the risk is greater than 100 or 200 cells $/ \mathrm{mm}^{3}$, but probably it is the same for patients with 195 and 205 cells/ $\mathrm{mm}^{3}$ counts. For a given cell count, the risk of developing PCP is higher in those patients with high HIV loads, compared to those with counts low or below the detection limits of the method. HIV viral load has been reported to be an independent risk factor for PCP development; however, recent research has reported the association between elevated HIV viral load and increased risk of PCP, regardless of $\mathrm{CD} 4 \mathrm{~T}$ cell counts and prophylactic treatment (20).

The variation, both in the specimens and in the methods used to carry out the detection of $P$. jirovecii was notorious in the reviewed studies, being $\mathrm{SS}$ and BAL specimens the most used, and among the methods DIF and nPCR, similar to those used in this study $(1,2,15-19)$. The SS was the most frequently specimen referred to the INHRR for the detection of $P$. jirovecii in this work. Although 


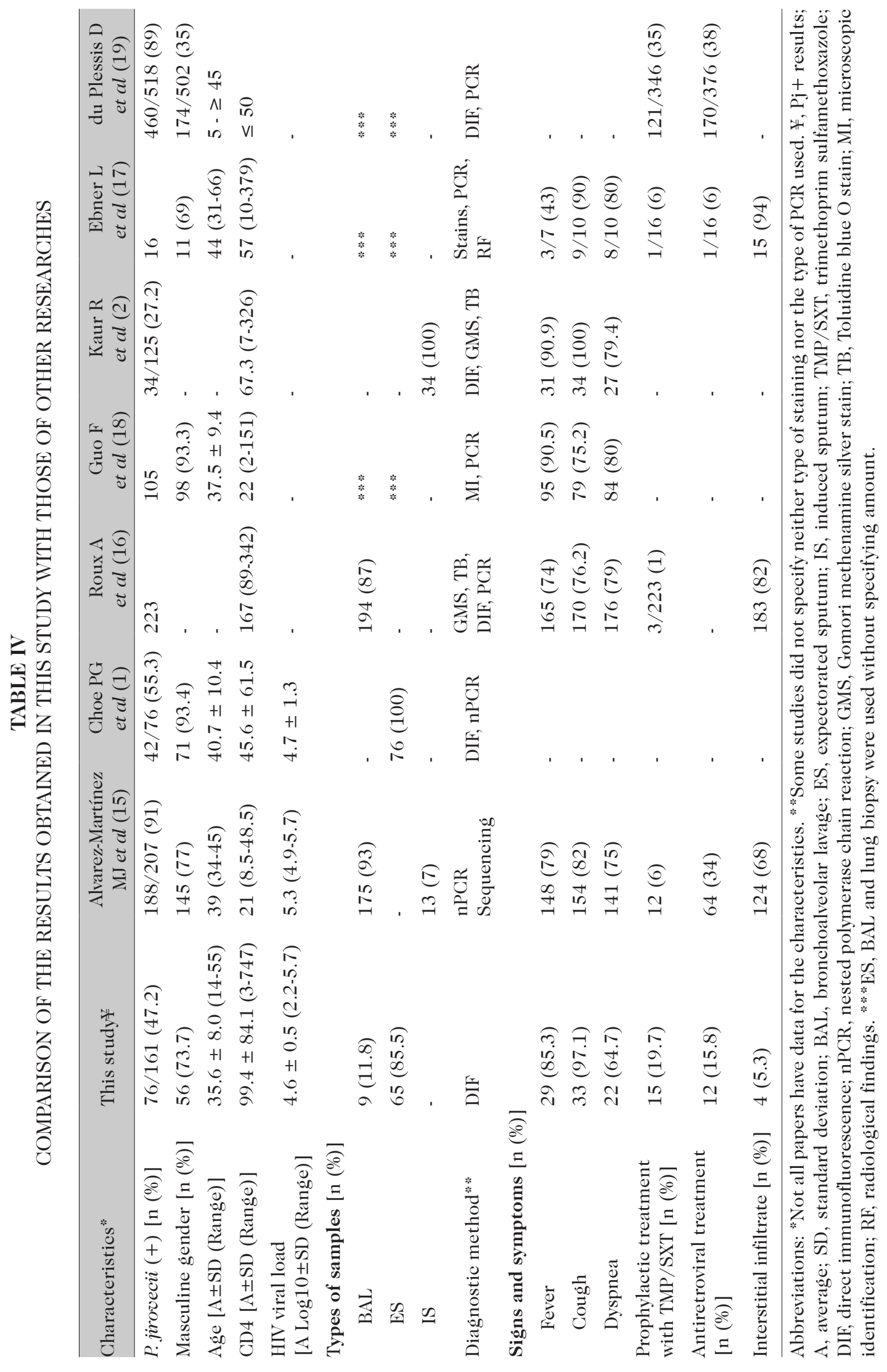


it has been described that it is not the ideal specimen for diagnosis, there are reports that have shown that it is sensitive enough to detect this microorganism in patients with HIV infection or AIDS, regardless of the method used $(1,3,19,21)$. Our experience in the PCP diagnosis and the results obtained in this work also support this statement $(4,6,7,9)$. It is important to obtain the specimen in optimal conditions, as well as having well trained and experienced staff in charge of the diagnosis. BAL is considered the ideal sample, but is obtained by an invasive procedure, which requires specialized personnel and expensive equipment (2). These characteristics make it an impractical specimen in hospitals with limited resources located in developing countries such as ours.

It has been demonstrated that nPCR is more sensitive for the detection of $P$. jirovecii than stains and even than DIF. The primers described by Wakefield et al., were chosen because the mitochondrial large subunit rRNA (mtLSUrRNA) gene is the most specific and sensitive for the detection of this fungus, with a detection threshold that can reach values of $0.5-1$ organism $/ \mu \mathrm{L}$ of specimen. The mtLSU rRNA is a multicopy gene in the $P$. jirovecii genome that contributes to the higher successful amplification rates, especially when used with nPCR. For this reason, this technique produced less false negative results and presented higher concordance with the results of conventional stains and DIF $(8,13,14)$.

Studies by other researchers have reported discrepancies observed between the results obtained by DIF and by nPCR. The results for nPCR have not been considered to be false positives and several interpretations have been proposed that will be discussed hereafter. The high nPCR sensitivity has allowed the detection of $P$. jirovecii several weeks before and after the presence of the fungus is demonstrated microscopically (probed PCP) (22-25). These findings are consistent with those obtained in experimental PCP studies, which demonstrated that the PCR was positive before obtaining positive results by histological techniques $(26,27)$. On the other hand, the detection of P. jirovecii DNA does not prove the viability of the fungus; some positive results obtained in nPCR may be due to recent infection, the presence of non-viable remains of a past infection or be product of the inhalation of non-viable $P$. jirovecii (28), assumptions that have promoted ideas about the acquisition and transmission of this fungus $(28,29)$.

Another explanation is that the use of prophylactic therapy for PCP can reduce the number of microorganisms, which cannot be detected in the stains (22-24). It has been reported that treatment with TMP/SXT reduces the amount of $P$. jirovecii which can be detected in respiratory samples (30). In addition, according to the results obtained by Davis et al., (28) although the use of TMP/ SXT high doses as an empirical treatment did not contribute to reduce the probability of colonization, the period between initiation of treatment and the realization of diagnostic tests may have been too short to achieve the elimination of $P$. jirovecii DNA. Although only 2 of $20 \mathrm{Pjc}+$ patients were receiving prophylactic treatment with TMP/ SXT at the time of fungus detection, and that the use of antimicrobial doses, as well as their duration and compliance, are unknown, the result obtained by Davis et al., (28) suggests a possible explanation for the discrepant results obtained in this study.

Finally, these discrepancies could be related to subclinical colonization, particularly in patients with respiratory symptoms (22-25). It is difficult to distinguish between colonization and infection in the case of Pjc + patients of this study, since all patients presented respiratory symptoms and clinical suspicion of PCP, however, the symptoms are non-specific and may be frequently associated to pneumonia of bacterial, viral and even mycotic etiology. It is possible that patients with HIV infection acquire $P$. jirovecii during their hospitalization, as suggested by the observation by Helweg-Larsen et al., (31) in 
which several patients had dissimilar results of colonization during the PCP episode. Colonization remains a state of uncertain clinical significance, therefore, in patients with respiratory symptoms and clinical suspicion of PCP, the discrepant results between DIF and nPCR should be interpreted with caution, taking into account both the patient's clinical symptoms and the result issued by the laboratory $(3,8,18)$.

On the other hand, the high frequency of CD4 T cell counts below 200 cells $/ \mathrm{mm}^{3}$ in the three groups of patients of this study, particularly in the $\mathrm{Pjc}+(85.7 \%)$ and the frequency of possible colonization (23.5\%), are similar to the results obtained by other investigators $(25,32,33)$, but different from those obtained in the study by Davis et al. (28), where the percentage of patients colonized with $P$. jirovecii was higher (58\%). Additionally, these investigators found that the colonization probabilities increased in patients with CD4 T cell count $<50$ compared to those with $>50$ cell counts, supporting the hypothesis that immunosuppression predisposes patients to colonization. This limit is lower than that reported in other studies $(1,2,15-19)$, and contrasts with the evidence that the risk of PCP increases with CD4 T cell counts lower than 200 cells $/ \mathrm{mm}^{3}$ (34). It could also be the reflection of the distribution of CD4 $\mathrm{T}$ cell counts from a population of HIV-infected patients whose samples refer to a particular center for the detection of $P$. jirovecii (28), a situation similar to that of our study. The possible colonization observed in this work, related to the decrease in CD4 $\mathrm{T}$ cell counts, is possibly due to a random event; however, it is consistent with studies that demonstrated this inversely proportional relationship $(25,32,33)$.

Unfortunately, in 32 of $76 \mathrm{Pj}+$ patients, nPCR could not be performed in parallel with DIF, because the necessary reagents were not available. In Venezuela, as well as in Latin America and other developing countries, the PCP diagnosis is limited by the absence of diagnostic methods in laboratories and difficulties in accessing medical care and treatment of the population $(11,12)$. Latin America is considered to be the most unequal region of the world, where poverty continues being one of the principal challenges. For this reason, we recommend the use of DIF with SS samples as the first diagnostic line for PCP in patients with HIV/ AIDS infection, especially in hospitals where it is not possible to obtain BAL and IS samples. In the event that the hospital does not have the diagnostic methods, samples should be sent to a reference center. This suggestion has also been endorsed by other authors $(1,2,19)$.

Co-infections in patients with HIV infection are frequent and this may be the reason why the most common was ALRTI. On the other hand, there were also TB, disseminated histoplasmosis and oral candidiasis, all of which are diseases that marked the presence of AIDS. These findings were similar to those of other studies $(2,16,18,19)$ and are related to the need to consider the PCP in the differential diagnosis of the ALRTI; this would imply introducing changes in the diagnostic protocols and in the routine use of wide spectrum antimicrobials, when the clinical findings are atypical (16). This last point was also documented in this study (Table II).

In developed countries, access to both HAART and prophylactic therapy are some of the reasons why the PCP frequency has declined in patients with HIV infection. However, as mentioned previously, this is not the case in developing countries such as ours (11). Particularly, in our country, it has been demonstrated that HIV/AIDS diagnosis is late. The time that passes between the moment of the diagnosis and the beginning of the HAART is of approximately 1 year. Among the reasons for this delay are the collapse of outpatient visits, limited access of the population to medical care, and the difficulty of performing CD4 T cell counts, viral load and diagnosis of opportunistic diseases, common situations in our hospital centers (35). All this is reflected in the low values of

Vol. 61(3): 196 - 211, 2020 
CD4 T cell counts and high viral loads of HIV in the patients evaluated in this study, also explaining the high frequency of PCP and the presence of other opportunistic diseases. In spite of these premises, similar results have been obtained in studies carried out in developed countries such as Spain, France and Switzerland (Table II) (15-17). Due to this, to diagnose PCP it is necessary to have a high index of clinical suspicion, opinion shared by other authors $(16,18)$.

The most frequent signs and symptoms presented by patients in this study were cough, dyspnea and fever, similar to those reported in other studies $(2,15-17)$. As previously mentioned, they are nonspecific, but a recent work has reported that the use of four or more clinical manifestations (cough, dyspnea, fever, chest pain and weight loss) added to an albumin value $<30 \mathrm{~g} / \mathrm{L}$ as predictive factors, would allow physicians to recognize the risk of $\mathrm{PCP}$ in advance, avoiding further deterioration of patient's condition (18).

The PCP diagnosis in developing countries tends to be clinical, supported in the evaluation of signs and symptoms, radiological findings, complementary laboratory tests and the patient history $(11,12)$. The physician makes a presumptive clinical diagnosis based on his findings, which does not necessarily lead to provide the most suitable treatment to the patient (36). It is very difficult for the physician to make decisions with a $100 \%$ certainty when the degree of uncertainty is high, since the signs, symptoms and radiological findings observed in PCP are common to other respiratory diseases such as $\mathrm{TB}$ and bacterial pneumonia, with which it is frequently mistaken. In these cases, values of sensitivity, specificity, and positive and negative predictive values calculated for each sign and symptom. are of limited use for the diagnosis (9). In clinical practice, diagnostic reasoning based on history, signs and symptoms usually, in $90 \%$ of the cases, guides the physician in the decision making and the request for the necessary complementary examinations. Therefore, the physician's ability to properly diagnose and handle PCP can have a significant impact on morbidity and mortality, especially when there are no complementary tests that confirm the etiological diagnosis at the hospital $(11,12,35,37)$.

In this work, in the $\mathrm{Pj}+$ patients, the most frequent radiological finding was the diffuse bilateral infiltrate followed by bilateral interstitial infiltrate, different results to those of other researches, where the diffuse bilateral interstitial infiltrate was the most frequent $(2,15-17)$. The classical radiological presentation of PCP in chest X-rays is the diffuse bilateral interstitial infiltrate, which is characterized by finely granular and/or reticular opacities, with the appearance of ground glass. However, almost any radiological presentation can be observed in PCP, including infiltrates in the upper lobes, asymmetric infiltrates, nodules, cavitations, spontaneous pneumothorax and images considered within normal limits (3). These findings are similar to those obtained by Kaur et al. (2), this study, and other previous Venezuelan study, which showed that the values of sensitivity, specificity and predictive values of radiological findings are low, due to the diversity of pathologies that HIV infection and AIDS patients have (9).

The retrospective nature of this work and the fact of reflecting the diagnostic experience of a referral center through passive surveillance, are important limitations that prevent the generalization of the results. Another significant limitation is the lack of data availability in the majority of patients and that a systematic monitoring of their clinical evolution cannot be performed. Nevertheless, and in spite of these limitations, the obtained results were very similar to those of other researches.

In Venezuela, spreading the advances and knowledge of medical mycology is a current need and should be accessible not only to specialists in this branch of microbiology, but also to the whole health team, in order 
to efficiently diagnose mycotic pathologies. Patients with HIV infection or AIDS, despite of carried out efforts, continue to suffer from diseases that should have been overcome, if it could rely on both the availability of resources for diagnosis in the hospital centers and, an educated population, who request and, at the same time, allow the necessary medical assistance as soon as possible (38).

Finally, PCP frequency in patients with HIV infection in this study is high but has been maintained over time. Colonization by $P$. jirovecii has an uncertain clinical significance, but this study provides evidence for the hypothesis that the condition of advanced immunosuppression increases the probability of colonization. DIF and nPCR are very useful for the detection of $P$. jirovecii, but are of limited access in hospital centers. We recommend the use of DIF with SS specimens as the first diagnostic line for PCP in patients with HIV infection, especially in hospitals where it is not possible to obtain BAL and IS specimens. The results obtained by $\mathrm{nPCR}$ should be interpreted with caution, taking into account the patient's clinical symptomatology.

\section{REFERENCES}

1. Choe PG, Kang YM, Kim G, Park WB, Park SW, Kim HB, Oh M, Chong Kim E, Kim NJ. Diagnostic value of direct fluorescence antibody staining for detecting Pneumocystis jirovecii in expectorated sputum from patients with HIV infection. Med Mycol 2014; 52: 326-330. doi: https://doi.org/10.1093/ mmy/myu002.

2. Kaur R, Wadhwa A, Bhalla P, Dhakad MS. Pneumocystis pneumonia in HIV patients: a diagnostic challenge. Med Mycol 2015; 53: 587-592. doi: https://doi.org/10.1093/ mmy/myv023.

3. Siegel M, Masur H, Kovacs J. Pneumocystis jirovecii pneumonia in human immunodeficiency infection. Semin Respir Crit Care Med 2016; 37: 243-256. doi: https:// doi.org/10.1055/s-0036-1579556.
4. Borelli K, Brito A, Rivas G, Panizo MM, Roldán Y. Diagnóstico de Pneumocystis carinii: Estudio comparativo entre inmunofluorescencia directa y la coloración histológica de Gomori-Grocott. Bol Soe Ven Microbiol 2000; 20: 46-52. Available from: http://ve.scielo.org/scielo.php?script $=$ sei_arttext $\&$ pid $=\mathrm{S} 1315$ $255620000001000 \overline{1} 0 \& \operatorname{lng}=$ es $\& \mathrm{nrm}=$ iso\& tlng $=$ es. Accesed 5 July, 2019.

5. Cruciani M, Mareati P, Malena M, Boseo O, Serpelloni G, Mengoli C. Meta-analysis of diagnostic procedures for Pneumocystis carinii pneumonia in HIV-infected patients. Eur Respir J 2002; 20: 982-989. doi: http:// doi.org/10.1183/09031936.02.01372002.

6. Panizo MM, Reviakina V, Navas T, Casanova K, Sáez A, Guevara RN, Cáceres AM, Vera R, Sucre C, Arbona E. Neumocistosis en pacientes venezolanos: diagnóstico y epidemiología (2001-2006). Rev Iberoam Micol 2008; 25: 226-231. doi: https://doi. org/10.1016/S1130-1406(08)70054-8.

7. Panizo MM, Alareón V, Reviakina V, Navas T. Evaluación de la técnica de PCR anidada para el diaǵnóstico de Pneumocystis jirovecii. Rev Soc Ven Microbiol 2009; 29: 136-139. Available from: http://ve.scielo. $\mathrm{org} / \mathrm{pdf} / \mathrm{rsvm} / \mathrm{v} 29 \mathrm{n} 2 / \operatorname{art} 13 . p d f$. Accesed 7 July, 2019.

8. Tomás AL, Matos O. Pneumocystis jirovecii pneumonia: current advances in laboratory diagnosis. OBM Genetics 2018; 2(4). https://doi.org/10.21926/obm.genet. 1804049.

9. Casanova K, Sáez A, Navas T, Reviakina V, Panizo M, Chiriboga D. Epidemiología de la neumocistosis. Med Interna (Caracas) 2006; 22(3): 207-226. Available from: http://svmi.web.ve/wh/revista/V22_ N3.pdf. Accesed 17 October, 2019.

10. Cermeño JR. Hernández de Cuesta I, Alcalá F, Áppice M. Pneumocystis j̈rovecii en centros hospitalarios del Estado Bolívar, Venezuela. Rev Biomed 2006; 17: 169-174. doi: https:// doi.org/10.32776/revbiomed.v17i3.454.

11. Calderón EJ, de Armas Y, Panizo MM, Wissmann G. Pneumocystis jirovecii pneumonia in Latin America. A public health problem? Expert Rev Anti Infect Ther 2013; 11: 565-570. doi: https://doi.org/10.1586/ eri.13.41. 
12. De Armas Rodríguez Y, Wissmann G, Müller AL, Pederiva MA, Brum MC, Brackmann RL, Capó De Paz V, Calderón EJ. Pneumocystis jirovecii pneumonia in developing countries. Parasite 2011; 18: 219 228. doi: http://doi.org/10.1051/parasite/2011183219.

13. Wakefield AE, Pixley FJ, Banerji S, Sinclair K, Miller RF, Moxan ER, Hopkin JM. Detection of Pneumocystis carinii with DNA amplification. Lancet 1990; 336: 451453. doi: https://doi.org/10.1016/01406736(90)92008-6.

14. Wakefield AE, Guiver L, Miller RF, Hopkin JM. DNA amplification on induced sputum samples for diaǵnosis of Pneumocystis carinii pneumonia. Lancet 1991; 337: 13781379. doi: https://doi.org/10.1016/01406736(91)93062-E.

15. Alvarez-Martínez MJ, Moreno A, Miró JM, Valls ME, Rivas PV, de Lazzaria E, Sued O, Benito N, Domingo P, Ribera E, Santín M, Sirera G, Segura F, Vidal F, Rodríguez F, Riera M, Cordero ME, Arribas JR, Jiménez de Anta MT, Gatell JM, Wilson PE, Meshnick SR, Spanish PCP Working Group. Pneumocystis jirovecii pneumonia in Spanish HIV-infected patients in the combined antiretroviral therapy era: prevalence of dihydropteroate synthase mutations and prognostic factors of mortality. Diag Microbiol Infec Dis 2008; 62: 34-43. doi: $\quad$ https://doi.org/10.1016/j.diaǵmicrobio.2008.04.016.

16. Roux A, Canet E, Valade S, Gangneux-Robert $\mathrm{F}$, Hamane $\mathrm{S}$, Lafabrie $\mathrm{A}$, Maubon $\mathrm{D}$, Debourgogne A, Le Gal S, Dalle F, Leterrier M, Toubas D, Pomares C, Bellanger AP, Bonhomme J, Berry A, Durand-Joly I, Magne D, Pons D, Hennequin C, Maury E, Roux P, Azoulay É. Pneumocystis jirovecii pneumonia in patients with or without AIDS, France. Emerg Infect Dis 2014; 20: 1490-1497. doi: http://doi.org/10.3201/ eid2009.131668.

17. Ebner L, Walti LN, Rauch A, Furrer H, Cusini A, Meyer AMJ, Weiler S, Huynh-Do U, Heverhagen J, Arampatzis S, Christe A. Clinical course, radiological manifestations, and outcome of Pneumocystis jirovecii pneumonia in HIV patients and renal transplant recipients. PLoS ONE 2016; 11: e0164320. doi: https://doi.org/10.1371/ journal.pone.0164320.

18. Guo F, Chen Y, Yang S-L, Xia H, Li X-W, Tong Z-H. Pneumocystis pneumonia in HIVinfected and immunocompromised nonHIV infected patients: a retrospective study of two centers in China. PLoS ONE 2014; 9: e101943. doi: https://doi.org/10.1371/ journal.pone.0101943.

19. Du Plessis D, Poonsamy B, Msimang V, Davidsson L, Cohen C, Govender N, Dawoode H, Karstaedtef A, Frean J. Laboratorybased surveillance of Pneumocystis jirovecii pneumonia in South Africa, 2006-2010. South Afr J Infect Dis 2016; 31: 8-13. doi: https://doi.org/10.1080/23120053.2015.1 118828.

20. The Opportunistic Infections Project Team of the Collaboration of Observational HIV Epidemiological Research in Europe (COHERE). Is it safe to discontinue primary Pneumocystis jiroveci pneumonia prophylaxis in patients with virologically suppressed HIV infection and a CD4 cell count $<200$ cells/ $\mu$ L? Clin Infect Dis 2010; 51(5): 611-619. doi: https://doi. org/10.1086/655761.

21. Pinlaor S, Mootsikapum P, Pinlaor P, Phunmanee A, Pipitgool V, Sithithaworn P, Chumpia W, Sithithaworn J. PCR diaǵnosis of Pneumocystis carinii sputum and bronchoalveolar lavage samples in immunocompromised patients. Parasitol Res 2004; 94: 213-218. doi: https://doi.org/10.1007/ s00436-004-1200-y.

22. Lipschick GY, Gill VJ, Lungren JD, Kovaes JA, Gill VJ, Nelson NA, Lundgren JD, Nielsen JO. Improved diaǵnosis of Pneumocystis carinii infection by polymerase chain reaction on induced sputum and blood. Lancet 1992; 340: 203-206. doi: https:// doi.org/10.1016/0140-6736(92)90469-J.

23. Olsson M, Elvin K, Lofdahl S, Linder E. Detection of Pneumocystis carinii DNA in sputum and bronchoalveolar lavage samples by polymerase chain reaction. J Clin Microbiol 1993; 31: 221-226. Available from: https:// jem.asm.org/content/jcm/31/2/221.full. pdf. Accesed 17 June, 2019.

24. Moonens F, Liesnard C, Brancard F, Van Vooren JP, Serruys E. Rapid simple and nested polymerase chain reaction for the diaǵnosis 
of Pneumocystis carinii pneumonia. Scand J Infect Dis 1995; 27: 358-362. doi: https:// doi.org/10.3109/00365549509032731.

25. Rabodonirina M, Raffenot D, Cotte L, Boibieux A, Mayençon M, Bayle G, Persat F, Rabatel F, Trepo C, Peyramond D, Piens MA. Rapid detection of Pneumocystis carinii in bronchoalveolar lavage specimens from human immunodeficiency virus-infected patients: use of a simple DNA extraction procedure and nested PCR. J Clin Microbiol 1997; 35: 2748-2751. Available from: https://jcm. asm.org/content/jcm/35/11/2748.full.pdf. Accesed 15 June, 2019.

26. Schluger N, Godwin T, Sepkowitz K, Armstrong D, Bernard E, Rifkin M, Cerami A, Bucala R. Application of DNA amplification to pneumocystosis: presence of serum Pneumocystis carinii DNA during human and experimentally induced Pneumocystis carinii pneumonia. J Exp Med 1992; 176: 1327-1333. doi: https://doi.org/10.1084/jem.176.5.1327.

27. Sepkowitz K, Schluger N, Godwin T, Armstrong D, Cerami A, Bucala R. DNA amplification in experimental pneumocystosis: characterization of serum Pneumocystis carinii DNA and potential $P$. carinii carrier states. J Infect Dis 1993; 168: 421-426. doi: https://doi.org/10.1093/infdis/168.2.421.

28. Davis JL, Welsh DA, Beard CB, Jones JL, Lawrence GG, Fox MR. Pneumocystis colonization is common among hospitalized HIV infected patients with non-Pneumocystis pneumonia. Thorax 2008; 63: 329-334. doi: http://dx.doi.org/10.1136/ thx.2007.088104.

29. Miller RF, Lindley AR, Copas A, Ambrose HE, Davies RJO, Wakefield AE. Genotypic variation in Pneumocystis jirovecii isolates in Britain. Thorax 2005; 60: 679-682. doi: http://dx.doi.org/10.1136/ thx.2004.039818.

30. Epstein LJ, Meyer RD, Antonson S, Strigle SM, Mohsenifar Z. Persistence of Pneumocystis carinii in patients with AIDS receiving chemoprophylaxis. Am J Respir Crit Care Med 1994; 150: 1456-1459. doi: https:// doi.org/10.1164/ajrcem.150.5.7952576.

31. Helweg-Larsen J, Tsolaki AG, Miller RF, Lundgren B, Wakefield AE. Clusters of Pneumocystis carinii pneumonia: analysis of person-to-person transmission by genoty- ping. QJM 1998; 91: 813-820. doi: https:// doi.org/10.1093/qjmed/91.12.813.

32. Leigh TR, Kangro HO, Gazzard BG, Jeffries DJ, Collins JV. DNA amplification by the polymerase chain reaction to detect subclinical Pneumocystis carinii colonization in HIV-positive and HIV negative homosexuals with and without respiratory symptoms. Respir Med 1993; 87: 525529. doi: https://doi.org/10.1016/09546111(93)90008-N.

33. Huang L, Crothers K, Morris A, Groner G, Fox M, Turner JR, Merrifield C, Eiser S, Zucchi P, Beard CB. Pneumocystis colonization in HIV-infected patients. J Eukaryot Microbiol 2003; 50: 616-617. doi: https:// doi.org/10.1111/j.1550-7408.2003. tb00651.x.

34. Masur H, Ognibene FP, Yarchoan R, Shelhamer J, Baird B, Travis W, Suffredini AF, Deyton L, Kovacs JA, Falloon J, Davey R, Polis M, Metcalf J, Baseler M, Wesley R, Gill VJ, Fauci AS, Lane HC. CD4 counts as predictors of opportunistic pneumonias in human immunodeficiency virus (HIV) infection. Ann Intern Med 1989; 111:223231. doi: https://doi.org/10.1059/00034819-111-3-223.

35. Lugo L, Miquilareno M, Figueredo A, Silva M, Rodríguez Morales AJ. Respuesta a la terapia antirretroviral altamente activa en pacientes de 50 años de edad o más viviendo con infección VIH/SIDA. Gac Med Caracas $2012 ; 120(4): 292-301$. Available from: http://www.anm.org.ve/anm/saciverrevista.php. Accesed April 22, 2019.

36. Randall Curtis J, Paauw DS, Wenrich MD, Carline JD, Ramsey PG. Ability of primary care physicians to diaǵnose and manage Pneumocystis carinii pneumonia. J Gen Intern Med 1995; 10: 395-399. doi: https:// doi.org/10.1007/BF02599841.

37. Elstein AS, Schwarz A. Clinical problem solving and diaǵnostic decision making: selective review of the cognitive literature. BMJ 2002; 324: 729-732. doi: https://doi. org/10.1136/bmj.324.7339.729.

38. Navas Blanco TM. Micología clínica: la necesidad de una nueva visión. Med Interna (Caracas) 2015 ; 31(4): 163-166. Available from: http://www.svmi.web.ve/ojs/index.php/medint/article/view/11. Accesed April 22, 2019.

Vol. 61(3): $196-211,2020$ 